\title{
AN ANALYSIS OF THE COSTS OF THE INITIAL PUBLIC OFFER ON THE POLISH MARKET AS DETERMINAL OF THEIR OF THEIR BEHAVIOURS
}

\begin{abstract}
Undertaking the decision to carry out the public offering requires maturity and great knowledge regarding the complex time- and capital-intensive IPO process from the owners. The main purpose of the deliberations conducted by an author is to define the concept of the initial public offering, the characteristics of the advantages and disadvantages, with particular emphasis on its costs as well as factors determining the success of the initial public offering on the stock market in Poland in the years 2008-2017. The calculations were based on information included in the current reports that - according to the binding law in Poland - the entity introducing securities to trading on the official stock exchange market is obliged to publish after subscription or sale of shares.
\end{abstract}

Keywords: first public offer, market, direct cost, indirect cost, stock exchange, share.

\section{INTRODUCTION}

Among an increasingly broader range of financing possibilities, implemented investment activities, a wide offer in this area is offered by the regulated stock market. This market, also subject to the international competition, concentrates the demand for financial instruments offered by issuers more and more effectively. It is a place for raising capital on more and more competitive conditions. As compared to others, alternative sources of financing, including private placements on a regulated market, it is easier to find investors and get a higher sale price of the offered securities. These securities are usually of a share or debt nature. Skillful use of the public market offer enables to provide the company with funds for development, to improve its market position gradually, find a strategic investor or create an attractive image among clients and contractors (Wisła, 2007).

The decision on the company's debut in the stock market is not strictly a financial choice, resulting only from the need to obtain funds necessary for its development, however, it undoubtedly has a strategic dimension. Making the company public makes is connected with the necessity of its earlier creation of the good image that will attract the interest of the investors and - as a consequence - will bring capital to the company. The success of the Initial Public Offering (IPO) is largely dependent on the quality of the conducted process,

\footnotetext{
${ }^{1}$ Elżbieta Ważna, PhD, The Institute of Economics and Management, The Bronisław Markiewicz State University of Technology and Economics in Jarosław, ul. Czarnieckiego 16, 37-500 Jarosław; e-mail: ela.wazna@op.pl. ORCID: 0000-0002-9174-4376.
} 
the involved entities and efficient communication with the participants of the capital market through a wide range of the information channels (Furmanik, 2017).

The main purpose of the author's deliberations is to define the concept of the initial public offering, the characteristics of the advantages and disadvantages, with particular emphasis on its costs and factors determining the success of the initial public offering on the stock market in Poland in the years 2008-2017. The research period which was chosen by the author was dictated in particular by events that took place in 2008 when the global financial crisis broke out and the crisis phenomena are still present in the economic and financial reality of the world. This will allow us to answer the question whether joint-stock companies in Poland also decided to conduct the initial public offering during the time of crisis and how the direct costs of raising capital through the IPO were changing.

\section{THE CONCEPT AND THE ESSENCE OF THE INITIAL PUBLIC OFFERING}

Pursuant to the definition included in the Act on Public Offering and Conditions Governing the Introduction of Financial Instruments to Organized Trading and Public Companies (Act of 25 July 2005...), 'a public offer is providing access to at least 150 people or to an unlimited addressee, in any form and manner, information about securities and conditions of their acquisition, constituting a sufficient basis for the decision to acquire these securities'. An important element of this definition that determines that the offer is 'public' is a wide circle of its addressees. All offers addressed to designated recipients, the number of which does not exceed 149, are legally treated as private offers ${ }^{2}$. In addition, all offers in which the addressee is unmarked are treated as public offers. All offers whose information is disseminated via mass media, including the internet, are of such nature and the information about a particular offer is available to all interested investors. At this point it is worth noting that conducting a public offer does not always have to be related with introduction of shares into organized trading, and in particular their introduction to trading on a regulated market. The mechanisms of the initial public offering in specific countries differ taking into account the manner of valuing shares and its further allocation, the role and share of the issuer, the underwriter and the investor. From the issuer's point of view, the optimal mechanism of this offer is one that enables to maximize the income from the issue of shares (Draho, 2004).

Currently, Polish law defines only the concept of public offering and it does not define the concept of the original public offering. However, it is easy to say that this is public offering that is being carried out for the first time. This means that before this offer is conducted, the company is non-public, i.e. the group of its shareholders is limited. In the case of public offers, it is important to provide investors with all the information that will allow them to assess the investment risk adequately. This is so important in the aspect that the offer can reach investors who do not have broad knowledge and experience in the capital market (Sieradzki, 2016). The issue of new shares can be carried out according to three main models:

- closed subscription, by directing shares only to current shareholders by implementation of their pre-emptive rights,

${ }^{2}$ In the period covered by the study, the criterion of the number of entities determining whether the offer was treated as public or as private has changed. In the period from January 2003 to July 2005. this limit was 300 people, in the period from August 2005 to April 2013 it was 100 people, and after that period 150 people. 
- private subscription, by submitting an offer to a marked recipient, most often a strategic investor,

- open subscription, by raising capital on the open financial market.

Under the terms of a closed subscription, the issue price determined by the current owners will take into account both the capital needs of the company and the financial capabilities of the shareholders. Possible underestimation of the value of shares (relative to book value and market value) and expectation of higher capital gains, discounting ones, e.g. earlier decisions regarding the distribution of net profit may be in their interest. This group of investors interested in the purchase of shares and maintaining their position in the company also expects future participation in the benefits resulting from the implementation of the anticipated investment projects covered by the acquired capital. It has the most comprehensive range of information about the company's intentions, as a result the scope of asymmetry of information, which does not always limit conflicts of interest between owners and management is the lowest here.

Resignation of subscription rights by shareholders and other mode of issuance may occur in cases when the market prices the company higher in relation to the estimated value of the investment projects. This may also apply when the following are expected:

- significant dispersion of shares to secure the liquidity of the market, acquisition of a larger block of shares by the owners than it results from pre-emptive rights,

- obtaining significant financial resources in the shortest possible time, gaining strategic investors, with possible appointment of entities responsible for the implementation of the development strategy,

- creating the possibility of setting the issue price via the market (e.g. making the issue public).

It is vital to pay attention to the situation in which the issue of shares is directed to a strategic investor that is supposed to ensure, among others, access to specialist know-how, more effective management methods, improve the competitive position on the market, often secure the implementation of a specific development strategy or reduce the dominance of the founders of the company. In this case, it is possible to negotiate the issue price that is favourable to the investor and the company directly, with its possible possibly increase for additional privileges (e.g. in the field of dividends or voting rights).

An open subscription requires market verification of the company's operations, and in this case a wider assessment of numerous factors determining the expected and actual share issue price is necessary. It is essential to pay attention to the highlighted stage of enterprise development and the adopted development strategy. This is always related to additional elements of risk and uncertainty, the need for extra information about investment plans, assessment of the future structural changes, which may reduce the chances of optimal determination of the issue price. The issuer expects full market acceptance of the assumptions of the development strategy, securing capital needs and accepting the expected benefits related to this. Two situations which may determine - to a different extent - the final level of the issue price should be distinguished:

1. The company is a public company and previous share issues are traded on the market and may constitute a possible basis for comparison for determining the price.

2. The initial public issuing of shares is made and possible comparison with similar companies is possible (with the assumed comparability criteria). 
In these cases, investors' assessments are made under conditions of a more or less effective market, different access to the market information and possibility of assessing the actual and future economic potential of the issuer as well as different levels of expected and accepted risk. Therefore, it is important to know and assess the factors that determine the final determination of the issue price which secures the expectations of both the issuer and the investor.

\section{FACTORS DETERMINING THE SUCCESS OF THE INITIAL PUBLIC OFFERING AS WELL AS ITS ADVANTAGES AND DISADVANTAGES}

The success of the public offering measured by the company's accomplished valuation, the scale and variety of demand for shares and its public reception is closely related to numerous factors influenced mainly by the issuer, its management and shareholders, but also professional advisors involved in the preparation of the transaction. In the literature, examples of these major elements influencing the level of the issue price include (Łukasik, 2010):

- the impact of the share issue on the company's ownership structure and the form of their subscription,

- size and type of capital needs of the company as well as capital management,

- the stage of the company's current development, its further development strategy,

- planned investments and the accompanying risk,

- the company's position on the market.

The fact that assessment of issuers and investors is made in the conditions of a more or less effective market, with a diversified access to information (asymmetry of information) regarding the current and future potential of a particular company is also of great importance while determining the share issue price (Golec, Wrońska, 2014).

D. Sukacz divides the factors determining the issue price into internal ones, directly related to the condition and perspectives of the company's development and other factors which include primarily the situation on the equity market, the condition where a specific industry is located, the size of the public offering, size and frequency of the public offers made by companies in the industry in which the company operates (Sukacz, 2005).

U. Malinowska also emphasizes that both in the group of issuers and investors, success depends on familiarization with the mechanisms of the capital market functioning and acquisition of relevant knowledge regarding the factors influencing the changes in share price levels (Malinowska, 2011). Furthermore, the intense development of the financial markets and the turbulence occurring on it have caused that the complex process of determining, forecasting stock prices should include the fundamental and market factors as well (Fig. 1).

That determine effectiveness of business entities and influence its economic value (economic added value) while assessing the risk of decisions and actions taken. The fundamental determinants of setting the issue price can be considered in two perspectives:

- retrospective, including the current economic position of the company,

- prospective, including the impact of the company's capital development on its market value.

In the first case, the current situation of the company, its financial condition, operational and financial risk and payment capability based on basic information included in financial reporting are analyzed. The fundamental factors in the retrospective approach refer to the current economic position of the company and assessment of the basic financial values, 
synthesizing past choices and actions (e.g. book value, capital and property structure, cash flow). At the same time, it is a preliminary assessment of securing the economic interests of the owners and the degree of the risk taken.

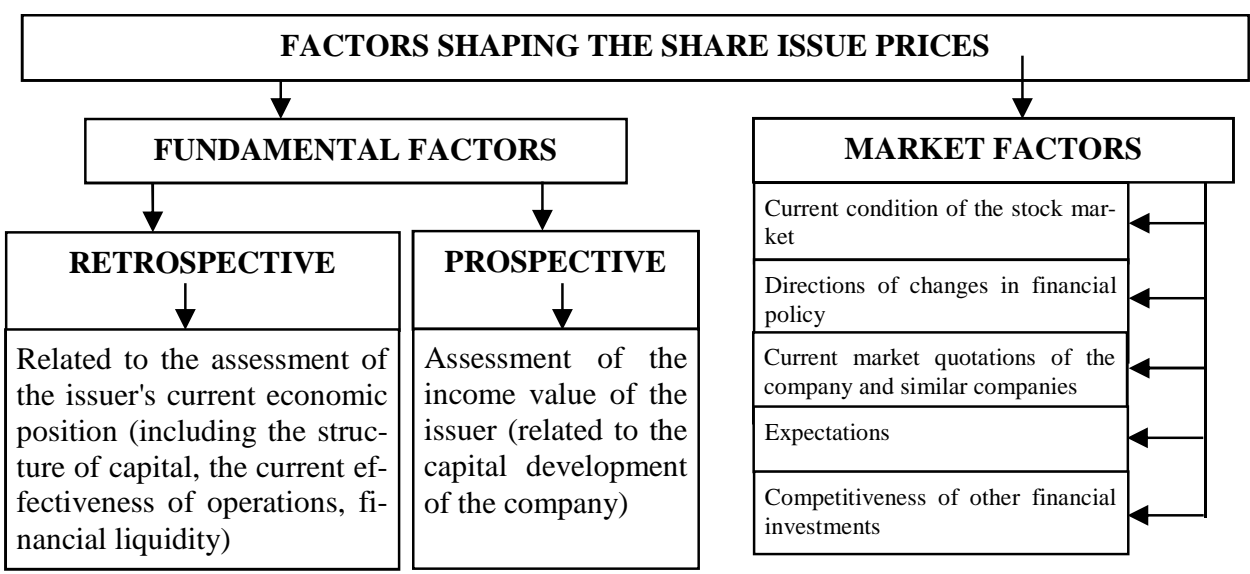

Figure 1. The scope of factors determining the level of the share issue price

Assessment of the current dividend policy, using the measures expressing: the level of dividend per share, the dividend rate, dividend coverage ratios may complete the analyses. However, attention should be paid to the various reactions of investors to the information on the applied dividend policy depending on the structure of shareholders, preferring current benefits to a varying extent (the so-called Dividend Magnetism) or future capital gains (the so-called profit magnetism).

In addition to retrospective factors, the information regarding the changes in the company's income position related to its capital development, the way capital is used and the change in the market position play an important role in determining the amount of the share issue price. The issuer will try to report the issue price to the expected income taking into account the fact that it 'sells' the right to participate in the economic effects of the company to future owners. However, this does not mean that assessment of the company's income value made by an issuer will be concurrent with the investor's assessment. The latter may strive to select companies that are undervalued in the investor's assessment as compared to the companies falling into a similar risk class. The prognostic assessments are difficult, requiring access to a wide range of the information about factors shaping the future economic value (economic added value) and risk areas, in conjunction with the assessment of effectiveness of the future investment plans financed by the raised capital (Karmańska, 2009).

Among the market factors, it should be emphasized that the choice of the right moment of the market determines the level of the issue price accepted by the market. Setting the correct issue price requires consideration of static and dynamic factors, using financial market analysis, matching technical and fundamental elements as well as the factual expectations and preferences of the investors. This is a difficult problem as decisions are made under conditions of uncertainty, it is necessary to take into account numerous elements that can occur with varying intensity at the moment of the actual market introduction and market 
verification of the earlier arrangements. The approximation of the issue price to the market price, i.e. the price accepted by market participants, requires a comparison and assessment of the profit rate expected by investors, with the expected profitability of the purchase of shares and the market interest rate. This is an area of the conflict of interest between the issuer and the investor that increases the cost of issuance and directs the investors' interest in other securities. The maximum share purchase price determined by the investor in the primary market, providing the expected rate of return does not have to correspond to the minimum price accepted by the issuer. The issuer's options may be different. On the one hand, it is possible to lower the issue price, its flexible shaping depending on development of the market situation, assess the ratio of the amount of expected capital to the identified needs or resign from raising capital in this segment of the financial market. On the other hand, appointment of the underwriter obliged to take over the shares that do not find buyers, and thus the risk of a deposit on the market with specific financial consequences for the issuer. Acceptance of the lower issue price may force a change in the direction of allocation of the acquired capital into areas ensuring higher economic efficiency. This is particularly important in the implementation of development processes where capital budget settlements may limit the possibilities of free shaping the level and cost of the acquired capital.

Table 1. The most important advantages and disadvantages of conducting IPO and listing on the regulated market

\begin{tabular}{|l|l|}
\hline \multicolumn{1}{|c|}{ Advantages } & \multicolumn{1}{|c|}{ Disadvantages } \\
\hline $\begin{array}{l}\text { Access to a wide range of investors that enables } \\
\text { to obtain large amounts. }\end{array}$ & $\begin{array}{l}\text { The debut of the stock market is connected with } \\
\text { the costs of conducting the offer and maintain- } \\
\text { ing the shares on the regulated market. }\end{array}$ \\
\hline $\begin{array}{l}\text { Better perception of the company by financial } \\
\text { entities (banks, venture capital funds), which al- } \\
\text { lows easier and cheaper acquisition of funds } \\
\text { outside the stock market. }\end{array}$ & $\begin{array}{l}\text { Maintaining shares in the stock market requires } \\
\text { regular informing investors about the issuer's } \\
\text { activity in the form of current, quarterly and an- } \\
\text { nual reports. }\end{array}$ \\
\hline $\begin{array}{l}\text { Increasing the company's credibility among its } \\
\text { contractors. }\end{array}$ & $\begin{array}{l}\text { Conducting the offer involves the disclosure of } \\
\text { significant data about the company's activities } \\
\text { to which their competition has access. }\end{array}$ \\
\hline $\begin{array}{l}\text { Regular and free advertising of the company in } \\
\text { the media. }\end{array}$ & $\begin{array}{l}\text { The sale of a large block of shares to investors } \\
\text { may mean a partial or total loss of control over } \\
\text { the company by its current shareholders. }\end{array}$ \\
\hline $\begin{array}{l}\text { Implementation of IPO is often associated with } \\
\text { the restructuring of the company which leads to } \\
\text { increased efficiency of its operation }\end{array}$ & \\
\hline $\begin{array}{l}\text { No need to reward shareholders for shared capi- } \\
\text { tal. Share capital does not require regular, oblig- } \\
\text { atory liquidity in the form of interest. }\end{array}$ & \\
\hline
\end{tabular}

Source: (Sieradzki, 2016).

From the point of view of the (existing) company owners, conducting the first public offering and introducing the shares to trading on the organized market has numerous advantages, yet, it also has certain drawbacks. Certainly, the biggest advantage of this process is the possibility of acquiring large funds due to the potential unlimited number of stock investors who can purchase the offered shares. The biggest disadvantages of maintaining 
shares in trading on the regulated market include the necessity to publish the financial data and all other relevant information that the company's competitors also have access to as well as investors. Furthermore, maintaining shares in the stock market involves the necessity to pay fees to the trading organizer, securities depository and market maker if the one has been contracted. The main advantages and disadvantages of conducting the IPO and listing of shares on the regulated market are presented in Table 1.

A thorough analysis of the advantages and disadvantages of introducing the company's shares to trading on a regulated market is very important and the management boards of companies often repeal the initial decision. This is most frequently related to the concerns about the possibility of losing control over the company or even its hostile takeover as well as loss of the current market position due to the necessity to publicize the sensitive market and financial data. These factors certainly have different meanings for individual companies. For those of them that have no other possibility to obtain financing, they will be of secondary importance (Sieradzki, 2016).

\section{COSTS RELATED TO THE CONDUCTING THE INITIAL PUBLIC OFFERING}

In addition to numerous benefits, the decision to carry out an IPO involves the costs. In the subject literature, the cost classification proposed by Ritter is known that distinguishes three cost groups (Ritter, 1987):

a) costs resulting from the underestimation of the issue price ${ }^{3}$,

b) underwriting costs (the gross underwriter spread)

c) other expenses, e.g. expenses related to legal advice, audit and printing related prospectus (Wawryszuk-Misztal, 2015).

In the empirical studies, the costs of stock exchange debuts are usually classified as direct and indirect costs.

Pursuant to the Polish law, direct public offer costs should be made public in the form of the current report which includes, among other, the information on the number of shares covered by the offer, issue price, value of inflows, values and types of offer costs consisting of:

a) the costs of preparing and conducting the offer,

b) costs of remuneration of underwriters ${ }^{4}$,

c) costs of drawing up the prospectus, including consultancy costs,

d) costs of offer promotion. In addition, the issuer should provide the information regarding the method of settlement of these costs in the accounting books and the manner of their inclusion in the financial statement (Regulation of the Minister of Finance of 19 February 2009, par. 33 section 1 item 12).

\footnotetext{
${ }^{3}$ One of the methods of measuring the underestimation of the share issue price is the original rate of return measured as the difference between the share price on the first trading day and the issue price divided by the issue price (Mamcarz, 2010).

4 These are costs resulting from the signed underwriting agreement. The Public Offering Act distinguishes between two types of underwriting agreements: service and investment [art. 14-15]. The subject of the service sub-service agreement is the acquisition by the underwriter of the service on its own account of all or part of the securities of a given issue in order to further their sale. In the case of an investment sub-issue, the underwriter undertakes to purchase, on its own account, all or part of the offered securities for which no subscriptions have been submitted within a specified period.
} 
Indirect costs are the benefits lost by the seller or issuer of shares when the share price on the first trading day is higher than the issue price or the selling price. Underestimation of the price of offered shares is a common phenomenon on the financial markets and constitutes a kind of incentive to purchase shares in a public offer.

The most important costs of conducting the public offering include remuneration of advisers helping the company at all stages of the process. This group includes an investment firm (a brokerage house or bank conducting the brokerage activity) that primarily works pursuant to a commission on the value of placed shares (success fee) as well as a legal adviser who is usually responsible for drawing up the legal documentation (including, first of all, the prospectus). Furthermore, it is the market practice to employ an image advisor (public relations /investor relations) who is experienced in the proper communication with the media and with individual investors. After the publication of the prospectus, companies usually conduct an advertising campaign in the media (mainly press and the Internet) in order to attract a wider group of the potential shareholders with their shares. Subsequently, the company must be prepared to pay fees to the Polish Financial Supervision Authority (approval of the prospectus and to cover the costs of supervision over the capital market), the National Depository for Securities (dematerialization of securities) and the WSE (admission and introduction to trading).

Generally, the higher the offer, the higher its absolute costs. At the same time, they constitute - of course - a much smaller value as compared to the value of shares issued than those in very small offers (up to 10 million PLN).

The statistical combination of values and number of IPO of the new issue shares is shown in the chart 1.

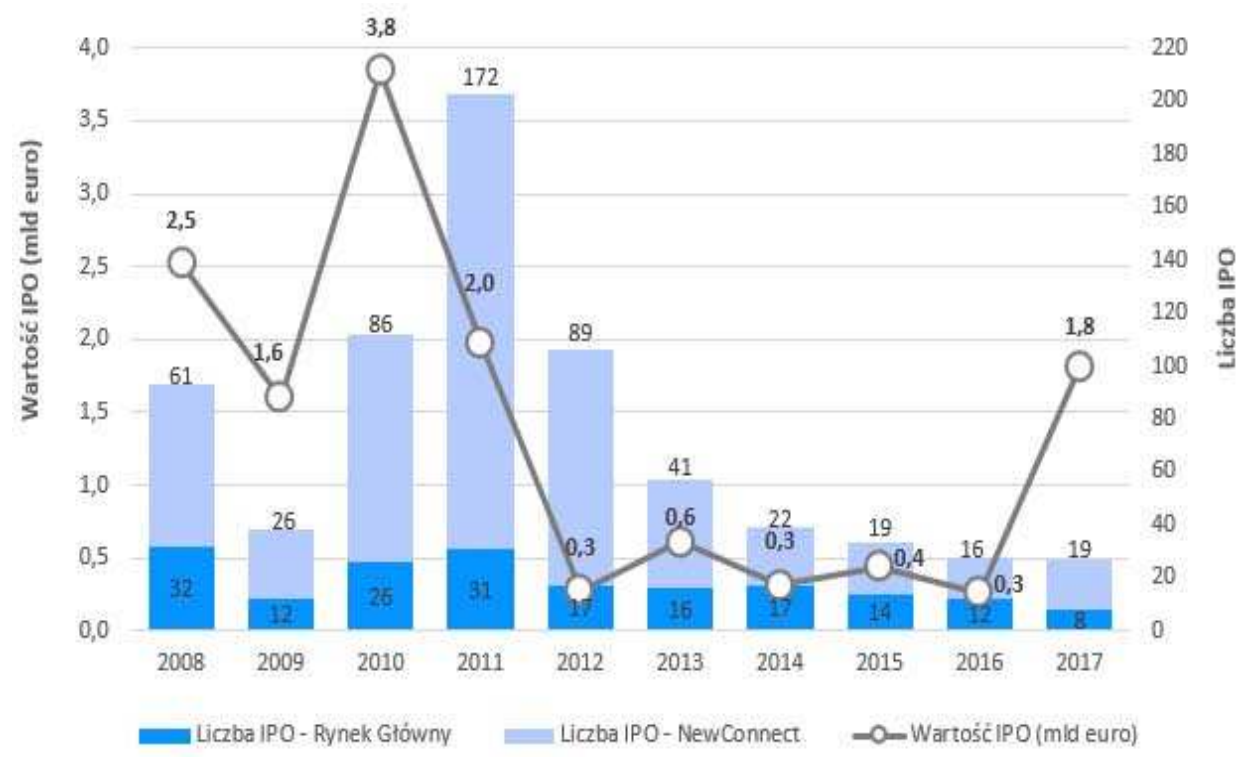

Chart 1. The statistical combination of values and number of IPO of the new issue

Source: author's own elaboration based on data from the Warsaw Stock Exchange, PwC, IPO Watch Europe, report for 2017. 
In 2018, 20 initial offers were recorded on the Warsaw Stock Exchange (which means a decrease in 7 offers as compared to 2017), 5 of them took place on the main market. The total value of IPO in Warsaw amounted to only 81 million EUR, which means the weakest year in terms of the value of the offers since 2003. The low activity on the primary market on the Warsaw Stock Exchange last year is particularly visible in comparison with the record year 2017 when the total value of IPO reached the level of 1.8 billion EUR (the offer of the company Play Communications SA worth 1 billion EUR was the largest debut).

In order to obtain the status of the listed company in 2009, it was necessary to pay approximately $10.4 \%$ of the value of the offer, which was a record sum in the analyzed period. The average cost was significantly raised by, among others, GPM Vindexus, specializing in receivables and debt collection services - the company obtained 1.75 million PLN from the issue bearing the cost of approx. 0.9 million PLN (51.5\%) (Kwiatkowska, 2010).

\section{ANALYSIS OF THE COSTS OF THE INITIAL PUBLIC OFFERING OF SHARES IN POLAND IN 2008-2017}

The analysis includes 100 domestic companies which conducted the IPO on the main share market of the WSE in 2008-2017 (Table 2). Due to the necessity of the accurate estimation of the costs of obtaining own capital and their structure in the research group, only companies whose public offer included only the issue of new shares were taken into account. The research did not include the entities that - as part of the public offering simultaneously issued new shares and sold existing shares.

Table 2. The number of debuts on the domestic exchange market in 2008-2017

\begin{tabular}{|l|c|c|c|c|c|c|c|c|c|c|}
\hline \multicolumn{1}{|c|}{ Year } & $\mathbf{2 0 0 8}$ & $\mathbf{2 0 0 9}$ & $\mathbf{2 0 1 0}$ & $\mathbf{2 0 1 1}$ & $\mathbf{2 0 1 2}$ & $\mathbf{2 0 1 3}$ & $\mathbf{2 0 1 4}$ & $\mathbf{2 0 1 5}$ & $\mathbf{2 0 1 6}$ & $\mathbf{2 0 1 7}$ \\
\hline $\begin{array}{l}\text { The number } \\
\text { of domestic } \\
\text { joint-stock } \\
\text { companies }\end{array}$ & 328 & 354 & 373 & 387 & 395 & 403 & 420 & 433 & 434 & 432 \\
\hline $\begin{array}{l}\text { Number of } \\
\text { listed com- } \\
\text { panies }\end{array}$ & 374 & 379 & 400 & 426 & 438 & 450 & 471 & 487 & 487 & 482 \\
\hline $\begin{array}{l}\text { The number } \\
\text { of debuts }\end{array}$ & 33 & 13 & 34 & 38 & 19 & 23 & 28 & 30 & 19 & 15 \\
\hline $\begin{array}{l}\text { Foreign } \\
\text { debuts }\end{array}$ & 25 & 25 & 27 & 39 & 43 & 47 & 51 & 54 & 53 & 50 \\
\hline $\begin{array}{l}\text { Number of } \\
\text { withdrawals }\end{array}$ & 10 & 8 & 13 & 12 & 7 & 11 & 8 & 13 & 19 & 20 \\
\hline
\end{tabular}

Source: author's own compilation on the basis of data from WSE.

The calculations were based on information included in the current reports which - according to the binding law in Poland - the entity introducing securities to trading on the official stock exchange market is obliged to publish after subscription or sale of shares.

The costs of share issue are largely fixed costs, hence in the case of emissions with a significant value, the share of emission costs in total inflows is relatively low. For this reason, the surveyed group of companies was divided into two groups: companies raising up to 50 million PLN of capital and above 50 million PLN. For each of these groups, share issue costs were analyzed separately, using descriptive statistics methods (Table 3). 
Table 3. Average inflows from issue and issue costs in terms of value in the period 2008-2017

\begin{tabular}{|c|c|c|c|c|c|c|}
\hline Year & Issue value & $\begin{array}{c}\text { No of } \\
\text { compa- } \\
\text { nies }\end{array}$ & $\begin{array}{c}\text { Average } \\
\text { value of } \\
\text { inflows from } \\
\text { issues in } \\
\text { thous. PLN }\end{array}$ & $\begin{array}{c}\text { Average } \\
\text { cost of } \\
\text { issue in } \\
\text { thous. PLN }\end{array}$ & $\begin{array}{c}\text { The average cost } \\
\text { of preparing } \\
\text { a prospectus and } \\
\text { consulting in } \\
\text { thous. PLN }\end{array}$ & $\begin{array}{l}\text { The average } \\
\text { cost of the } \\
\text { offer in } \\
\text { thous. PLN }\end{array}$ \\
\hline \multirow{2}{*}{2008} & $<50 \mathrm{mln}$ PLN & 12 & 12,308 & 957 & 327 & 266 \\
\hline & $>50 \mathrm{mln}$ PLN & 4 & 628,772 & 9,178 & 3,376 & 2,451 \\
\hline \multirow{2}{*}{2009} & $<50 \mathrm{mln}$ PLN & 7 & 9,883 & 1,091 & 570 & 175 \\
\hline & $>50 \mathrm{mln}$ PLN & 2 & $3,248,405$ & 25,391 & 5,751 & 1,659 \\
\hline \multirow{2}{*}{2010} & $<50 \mathrm{mln}$ PLN & 6 & 18,858 & 2,322 & 1,320 & 234 \\
\hline & $>50 \mathrm{mln}$ PLN & 3 & 89,904 & 5,169 & 1,668 & 289 \\
\hline \multirow{2}{*}{2011} & $<50 \mathrm{mln}$ PLN & 3 & 32,154 & 2,457 & 1,207 & 534 \\
\hline & $>50 \mathrm{mln}$ PLN & 1 & 118,500 & 6,372 & 1,263 & 782 \\
\hline \multirow{2}{*}{2012} & $<50 \mathrm{mln}$ PLN & 4 & 18,054 & 3,251 & 1,235 & 504 \\
\hline & $>50 \mathrm{mln}$ PLN & 0 & - & - & - & - \\
\hline \multirow{2}{*}{2013} & $<50 \mathrm{mln}$ PLN & 7 & 18,987 & 1,148 & 351 & 169 \\
\hline & $>50 \mathrm{mln}$ PLN & 2 & 98,730 & 5,365 & 1,906 & 445 \\
\hline \multirow{2}{*}{2014} & $<50 \mathrm{mln}$ PLN & 3 & 14,526 & 1,134 & 358 & 141 \\
\hline & $>50 \mathrm{mln}$ PLN & 1 & 50,520 & 2,961 & 2,247 & 193 \\
\hline \multirow{2}{*}{2015} & $<50 \mathrm{mln}$ PLN & 3 & 60,543 & 3,421 & 1,342 & 539 \\
\hline & $>50 \mathrm{mln}$ PLN & 2 & 16,573 & 2,465 & 467 & 1,342 \\
\hline \multirow{2}{*}{2016} & $<50 \mathrm{mln}$ PLN & 4 & 4,325 & 2,579 & 1,372 & 690 \\
\hline & $>50 \mathrm{mln}$ PLN & 2 & 3,567 & 968 & 2,682 & 489 \\
\hline \multirow{2}{*}{2017} & $<50 \mathrm{mln}$ PLN & 3 & 3,890 & 1,896 & 478 & 2,412 \\
\hline & $>50 \mathrm{mln}$ PLN & 1 & 7,320 & 1,248 & 493 & 689 \\
\hline
\end{tabular}

Source: Author's own compilation based on WSE prospectuses.

The table above shows that 432 companies debuted in the years 2008-2017, 50 foreign entities introduced their shares to trading on the WSE market, of which 41 companies carried out a new share issue. The majority of foreign companies were the entities that chose the WSE as the only place of quoting their shares. The factor conducive to the increase in the number of foreign entities on the WSE was entry into EU structures. First of all, these were companies from other EU countries that introduced shares to trading on the WSE.

Poland's accession to the European Union improved the image of our market in the eyes of foreign investors, which contributed to a greater inflow of foreign capital into the stock market. The stock exchange is often referred to as the economy barometer. Therefore, if indeed the trends prevailing in the stock market are caused by the economic situation of a specific country, enterprises operating in this market also experience these changes. Consequently, the macroeconomic situation changes into microeconomic. However, the market value of the company is not only a reflection of the market situation. To a large extent, it is shaped by decisions made within the organization. The skills of the management and the level of business risk of the enterprise are of crucial importance. However, it should be noted that the level of risk is affected not only by microeconomic factors but also macroeconomic factors, such as (Szyszko, 2000):

- unfavourable economic situation, 
- imprecisely estimated level of inflation,

- rapid changes in the market situation,

- changes in the fiscal and monetary policy (Paździor, 2008).

The analysis allows to state that in the case of issues up to 50 million PLN, statistically significant differences were noticed only in the case of the issue price and the cost of preparing the prospectus, i.e. those costs were higher only in the years 2008-2015. In the same period, one can notice a reduction in the promotion costs of the offer, which may be the result of a crisis, however, this change is not statistically significant. While analyzing the cost structure, the following are noted: the increase in the share of the costs of preparing the prospectus, the reduction in the share of the costs of preparing the offer and its promotion, although these differences are also not statistically significant. A similar situation also applies to companies raising more than 50 million PLN of capital.

The analysis allows to state that in the case of issues up to 50 million PLN, statistically significant differences were noticed only in the case of the issue price and the cost of preparing the prospectus, i.e. those costs were higher only in the years 2008-2015. In the same period, one can notice a reduction in the promotion costs of the offer, which may be the result of a crisis, however, this change is not statistically significant. While analyzing the cost structure, the following are noted: the increase in the share of the costs of preparing the prospectus, the reduction in the share of the costs of preparing the offer and its promotion, although these differences are also not statistically significant. A similar situation also applies to companies raising more than 50 million PLN of capital.

The range of the results obtained in the analyzed period can also be explained by the fact that since 2007 we have had to deal with a significant and long-lasting upward trend in share prices, which not only encouraged companies to enter the stock market, however, it also enabled the investors to achieve high rates on the day of their debut. In 2008 when the stock exchange already had a complete financial crisis, the situation was not as favourable as before. Undoubtedly, this year, companies were less able to use the underestimation of the share issue price as a signal. In contrast to the year 2007, sending a stronger signal would require determining the lower share issue prices, which would reduce revenue from issuance. The situation in this respect is improving in 2009 , however, the number of debuting companies was still small.

The financial crisis significantly changes the operating conditions of enterprises and as a result - influences their decisions (Porada-Rochon, 2013). The effect of the crisis is usually a limited access to capital. Enterprises postpone investment projects while waiting for more favourable conditions when it is easier to raise capital and the number of the profitable investment projects increases (Puławski, 2013).

On the financial markets during the crisis there is a significant reduction in the number and value of IPOs (Henry, Gregoriou, 2014), which was also the case at the Warsaw Stock Exchange (Puławski, 2013). In this context, the question arises as to whether and how in the aftermath of the financial crisis the direct costs of raising capital through the IPO change. It can be assumed that in the conditions of a crisis the tendency of enterprises to incur optional costs, for example related to the promotion of the offer, is changing. At the same time, entities cooperating with the company in the run-up to their debut on the WSE may be tempted to reduce the fees charged as a result of the reduced demand for their services. It is also impossible to ignore the fact that the financial crisis negatively affects the amount 
of inflows from the issue of shares and the relationship between expected and actual inflows.

\section{ENDING}

The initial public offering and introduction of shares to stock exchange trading enable companies to take full advantage of the opportunities offered by the stock market. Not only do the companies collect the necessary capital for further development but also they undoubtedly gain credibility and prestige, which owners and managers of companies are increasingly dependent on (to improve the competitive position in the target market). The issue of shares via the stock exchange also opens the possibility of benefiting from subsequent issues of securities in the future. Obtaining the status of a listed company also enables wider access to funds that are in the possession of a large number of entities actively operating on the trading floor.

The obtained results allow to state that the objective set at the beginning of the work was accomplished. It should be emphasized that as a result of the financial crisis the costs of issuance of shares under the IPO increased. This phenomenon can be observed only in the case of issues with a value of 50 million PLN with regard to 'large' emissions.

At the same time, it is worth noting that the subject of undervaluation of the initial offers is so extensive that it requires further work because a significant part of the factors determining the success of the public share issue may be exogenous, not always dependent on the issuer's activities. It may also be a consequence of an information gap on the part of investors, treating it as an additional investment risk. In the situation of a public share issue, this may also indicate a lack of the appropriate activities of the issuer in the area of active investor relations. Therefore, the needs of the modern market require active communication with the market, increase its information efficiency, which will allow the to set the issue price of the shares properly at the stage of obtaining the capital, taking into account the investor's and issuer's expectations and limit the phenomenon of undervaluation (re-evaluation) of public offers. The conducted analysis has allowed to draw the following conclusions:

- the number and value of the issue of new shares are sensitive to changes in the stock market situation,

- the costs of public subscription of shares in relation to the issue value are relatively high in the case of smaller emissions and decrease as the value of the issue increases,

- the companies, while conducting a public subscription of shares, relatively rarely use the services of investment underwriters.

\section{REFERENCES}

Draho, J. (2004). The IPO Decision. Why and How Companies Go Public, Edward Elgar Publishing, Cheltenham, UK-Northampton, USA.

Furmanik, M. (2017). Uwarunkowania sukcesu debiutu giełdowego na przykładzie Korporacji budowlanej Pekabex SA. „Finanse, Rynki Finansowe, Ubezpieczenia” No. 5/(89), part 2.

Karmańska, A. (2009). Wartość ekonomiczna w systemie informacyjnym rachunkowości finansowej. Warszawa: Difin.

Kwiatkowska, M. (2010). Ubiegłoroczni debiutanci na parkiecie zaptacili za obstuge ofert ponad 90 mln zt. „Dziennik Gazeta Prawna” No. 4. 
Łukasik, G. (2010). Fundamentalne i rynkowe czynniki ustalania ceny emisyjnej akcji. „Annales Universitatis Mariae Curie-Sklodowska - Polonia Sectio H”, Vol. XLIV, t. 2.

Golec, M., Wrońska, E. (2014). Wycena kapitału wtasnego w procesie IPO. Studia Ekonomiczne” No. 198, part 2. Wydawnictwo Uniwersytetu Ekonomicznego w Katowicach.

Malinowska, U. (2011). Analiza fundamentalna przedsiębiorstwa [w:] Panfil, M., Szablewski, A., red., Wycena przedsiębiorstwa: od teorii do praktyki. Warszawa: Poltext.

Puławski, M. (2013). Koszt pierwszej oferty publicznej na rynku akcji w Polsce w latach 2008-2012. „Zeszyty Naukowe Uniwersytetu Szczecińskiego” No. 768, „Finanse, Rynki Finansowe, Ubezpieczenia” No. 63.

Ritter, J.R. (1987). The costs of going public. "Journal of Financial Economics” Vol. 19, No. 2.

Sieradzki, R. (2016). Niedowartościowanie pierwotnych ofert publicznych na przykładzie akcji notowanych na Giełdzie Papierów Wartościowych w Warszawie. Rozprawa doktorska. Uniwersytet Ekonomiczny w Krakowie.

Sukacz, D. (2005). Pierwsze oferty publiczne na rynkach kapitałowych. Warszawa: CeDeWu. Wawryszuk-Misztal, A. (2015). Bezpośrednie koszty emisji akcji w pierwszej ofercie publicznej na GPW w Warszawie. „Prace Naukowe Uniwersytetu Ekonomicznego we Wrocławiu, Zarzadzanie finansami firm - teoria i praktyka” No. 412.

Wisła, W. (2007). Rynek oferty publicznej jako odzwierciedlenie zmian zachowań spótek kapitałowych [in:] Kopcińska, D., red. nauk., Zachowania rynkowe w teorii i praktyce, Szczecin: Wydawnictwo Uniwersytetu Szczecińskiego.

DOI: 10.7862/rz.2019.mmr.15

The text was subitted to the editorial ofice: January 2019.

The text was accepted for publication: June 2019. 
